\title{
The possible role of Kallikrein-6, 7, and potassium channel proteins in Alzheimer's disease
}

\section{Alzheimer hastalığında Kallikrein-6, 7 ve potasyum kanal proteinlerinin \\ olası rolü}

Erkut Baha BULDUK¹ (ID), Filiz YILDIRIM² (ID), Zuhal YILDIRIM³ (ID)

\section{ABSTRACT}

Objective: Although the formation mechanism of Alzheimer's Disease (AD) is not known with certainty, two major proteins, beta amyloid of senile plaques and tau protein of neurofibrillary tangels are responsible for $A D$. One of the major factors in the development of the disease is the formation of in soluble amyloid deposits, and the other one is the increased tau phosphorylation. Kallikreins (KLK's) are a sub-family of serine proteases that play a role in the etiology of $A D$ which is characterized by neuronal damage and loss of function.Kallikrein (KLK)-6 and KLK-7 are known to be age-related protease and are found at high levels in the central nervous system (CNS). It was previously shown to be involved in proteolysis of extracellular proteins implicated in neurodegenerative diseases such as AD. In this study, we aimed to investigate the possible role of KLK-6 and KLK-7 in the pathogenesis of $A D$ and the relationship between potassium channel proteins.

Methods: A total of 35 Alzheimer's patients over the age 65 years, followed-up by Polatlı Duatepe Government Hospital and 35 healthy individuals (control group) admitted to the neurology clinic for routine screening with cognitive status considered normal were included in this study. After a 12-hour hunger, KLK-6 and KLK-7 were measured with

\section{ÖZET}

Amaç: Alzheimer hastalığının $(\mathrm{AH})$ olușum mekanizması kesin olarak bilinmemekle birlikte AH'dan sorumlu bașlıca iki protein, senile plakların yapısındaki beta amiloid ve nörofibriler yumakların yapısındaki tau proteinidir. Hastalığa yol açan en önemli etmenlerden biri çözünür olmayan amiloid çökeltilerin olușumu, diğeri ise artmıș tau fosforillenmesidir. Kallikreinler, nöronal hasar ve ișlev kaybı ile belirgin AH'nın etiyolojisinde rol oynayan, serin proteazların bir alt familyasıdır. Kallikrein (KLK)-6 ve KLK-7'nin merkezi sinir sisteminde (MSS) yüksek seviyelerde bulunan yașa bağlı proteaz olduğu bilinmektedir. Daha once AH'ı gibi nörodejeneratif hastalıklarda yer alan hücre dıșı proteinlerin proteolizine karıștığı gösterilmiștir. Bu çalıșmada KLK-6 ve KLK-7'nin AH patogenezindeki olası rolünü ve potasyum kanal proteinleri arasındaki ilișkiyi araștırmayı amaçladık.

Yöntem: Çalıșmaya Polatlı Duatepe Devlet Hastanesinde takip edilen yașları 65'in üzerinde olan $35 \mathrm{AH}$ ve rutin tarama amacıyla nöroloji polikliniğine bașvuran kognitif durumu normal olarak değerlendirilen 35 sağlıklı birey (control grubu) dahil edildi. 12 saat açlığı takiben antekübital venden alınan kan örnekleri

${ }^{1}$ Attlım University, Faculty of Medicine, Department of Neurosurgery, Ankara

${ }^{2}$ Polatlı Duatepe Government Hospital, Clinic of Internal Medicine, Ankara

${ }^{3}$ Ankara Health Directorate, Public Health Services Presidency, Ankara

İletişim / Corresponding Author : Filiz YILDIRIM

Karapınar Eskişehir yolu üzeri İstiklal mah. Abdülaziz cad. No:2, Polatlı, Ankara, Türkiye

E-posta / E-mail :drfyildirim@yahoo.com

DOI ID : 10.5505/TurkHijyen.2020.50374

Bulduk EB, Yıldırım F, Yıldırım Z. The possible role of Kallikrein-6, 7, and potassium channel proteins in Alzheimer's disease Turk Hij Den Biyol Derg, 2021; 78(2): 125 - 132 
inwardly rectifying potassium channel protein (KCNJ3), and two-pore potassium channel protein (KCNK9) levels were measured by the Enzyme-Linked Immuno Sorbent Assay (ELISA) in the serum of the blood samples which were taken from the antecubital vein after centrifuging for 10 minutes at $2500 \mathrm{xg}$. The differences between the two groups were tested by $\mathrm{T}$ - test. A value of $\mathrm{p}<0.05$ was considered statistically significant.

Results: All the groups were matched for age and gender, but not statistically significant difference was observed ( $p>0.05)$. According to our findings, serum KLK6 and KLK-7 levels of Alzheimer's group were significantly increased $(p<0.05)$. A significant difference was not detected when the levels of serum KCNJ3 and KCNK9 of the Alzheimer's group compared with the control group $(p>0.05)$.

Conclusion: It is thought that the failure in preventing the abnormal protein folding and accumulation leads to $A D$ in the brain. According to the findings of the present study, a positive correlation was detected between the levels of KLK-6 and KLK-7 and AD's pathology.

Key Words: Alzheimer's disease, Kallikrein-6, Kallikrein-7, KCNJ3, KCNK9 $4^{\circ} C^{\prime}$ 'de $2500 x g$ 'de 10 dakika santrifüj edilerek, serum örneklerinde KLK-6 ve KLK-7 ile içeri doğru düzeltici potasyum kanalı (KCNJ3) ve iki gözenekli potasyum kanalı (KCNK9) protein düzeyleri enzim-bağımlı immunosorbent assay (ELISA) ile ölçüldü. Gruplar arasındaki fark T-test ile incelendi. $\mathrm{p}<0.05$ istatistiksel olarak anlamlı kabul edildi.

Bulgular: Gruplar arasında yaș ve cinsiyet açısından bir fark saptanmadı ( $p>0.05)$. Alzheimer grubu control grubu ile karșılaștırıldığında serum KLK-6 ve KLK-7 düzeyleri anlamlı olarak artarken $(\mathrm{p}<0.05)$, KCNJ3 ve KCNK9 protein düzeylerinde bir fark saptanmadı $(p>0.05)$.

Sonuç: Beyinde anormal protein katlanmasının ve birikmesinin önüne geçilememesinin AH'ye yol açtığı düșünülmektedir. Bu araștırmanın bulgularına göre KLK6 ve KLK-7 düzeyleri ile AH'nın patolojisi arasında bir ilișki saptandı.

Anahtar Kelimeler: Alzheimer hastalığı, Kallikrein-6, Kallikrein-7, KCNJ3, KCNK9

\section{INTRODUCTION}

Neurodegenerative disorders are widely known healthy problems for elderly people. Aging is considered as the major risk factor in most neurodegenerative disorders. Alzheimer's Disease $(A D)$ is the most common neurodegenerative disorder characterized by a selective neuronal cell death associated with two hallmark pathological lesions. The intracellular neurofibrillary tangles (NFTs) and extracellular amyloid deposits in the form of senile plaques (1). The etiological events leading to $A D$ pathogenesis have not been clearly defined. One of the major factors in the development of the disease is the formation of insoluble amyloid deposits, and the other one is the increased tau phosphorylation (2).

Kallikreins (KLK's) are a sub-family of serine proteases that play a role in the etiology of $A D$, which is characterized by neuronal damage and loss of function. Fifteen Kallikrein (KLK)-related peptidase family proteins have been identified and act in a complex network as a cascade reaction (3).

KLK-6 is a major KLK-related peptidase protein in the central nervous system (CNS). KLK-6 is widely expressed in several cells $(3,4)$. The KLK-7 in the human tissue, a chymotrypsin-like cool protease, causes desquamation and catalyzes the inter-adhesive 
structures in the corneous skin layer. In this way, KLK-7 plays roles in cancer invasion and metastasis. However, it was emphasized that kallikrein (KLK-5, 6, $7,8,11$ ) may be a new cancer marker in other types of tumors outside the CNS tumors (ovary, breast, prostate) (5).

Especially the brain and nervous system diseases, genetically-induced diseases, and sensory system disorders occur because of the mutations in the genes of potassium channels $(6,7)$. Potassium channels act in a wide range of physiological functions which include the regulation of heartbeat rate, insulin release, electrolyte transport, and immune system functions (8). In addition, there might be a connection between epilepsy, cardiac rhythm, musculoskeletal diseases, and hereditary diseases like diabetes and potassium canal disorders (9-12). Inwardly rectifying potassium channels (KCNJ3) transmit potassium ions inwards not outwards. This type of potassium channel is activated by hyperpolarization not by depolarization, unlike other potassium channels. The main function of $\mathrm{KCNJ3}$ is to stabilize the potential of the resting membrane (13). Two-pore potassium channels (KCNK9) are continuously open in the potential of the physiological membrane, and in this way, help to adjust the membrane potential at resting time (14, 15).

The aim of this study was to investigate the role of KLK's and potassium channel proteins in the pathogenesis of $A D$ by measuring the serum KLK-6, 7 and KCNJ3, KCNK9 protein levels of Alzheimer's patients.

\section{MATERIAL and METHOD}

A total of 35 Alzheimer's patients aged over 65 years, followed-up by Polatlı Duatepe Government Hospital, and 35 healthy individuals (control group) admitted to the neurology clinic for routine screening with cognitive status considered normal, were included in this study. For cognitive assessment, Mini-
Mental State Examination (MMSE) and clock drawing tests were performed. The diagnosis of AD was made according to Diagnostic and Statistical Manual for Mental Disorders (DSM-IV) and National Institute of Neurological and Communicative Disorders and Stroke and the $A D$ and Related Disorders Association (NINCDS-ADRDA) criteria after cognitive assessment and neuroimaging performed using magnetic resonance (MR). Clinical Dementia Rating Scale (CDR) scores of the patients with $A D$ were 1 and over. All the subjects were nonsmokers, nonalcohol users, and also did not have anemia, malnutrition, thyroid, Diabetes mellitus, hypertension, chronic renal failure, chronic inflammatory, and cardiovascular diseases. They were not taking any supplements such as vitamins and/ or antioxidants. The present study was carried out according to the Eskișehir Osmangazi University Clinic Research Committee and Human Ethical Committee Regulations. After a 12-hour hunger, the KLK-6, KLK7, KCNJ3, and KCNK9 levels were measured by the Enzyme-Linked Immuno Sorbent Assay (ELISA) in the serum of the blood samples which were taken from the antecubital vein afterbeing centrifuged for 10 minutes at $2500 \times$ g.

\section{Statistical analysis}

The data were analyzed using Statistical Package for the Social Sciences (SPSS, version 20.0, Chicago, IL, USA) statistics program. The differences between the two groups were tested by $T$ - test. A value of $p<0.05$ was considered statistically significant.

\section{RESULTS}

All the groups were matched for age and gender, but not statistically significant difference was observed ( $p>0.05)$. The levels of KLK-6 and KLK-7 in the serum were significantly higher in the Alzheimer's group than in the control group $(p<0.05)$. A significant difference was not detected when the levels of serum KCNJ3 and KCNK9 of the Alzheimer's group compared with the control group ( $p>0.05)$ (Table 1). 
Table 1. The serum KLK-6, KLK-7, KCNJ3, and KCNK9 levels in Alzheimer's patients and the control group (Mean \pm SD).

\begin{tabular}{|l|c|c|}
\multicolumn{1}{|r}{ Groups } & $\begin{array}{c}\text { Alzheimer's } \\
(\mathrm{n}=35)\end{array}$ & $\begin{array}{c}\text { Control } \\
(\mathrm{n}=35)\end{array}$ \\
\hline F/M & $28 / 7$ & $28 / 7$ \\
\hline Age (year) & $80.218 \pm 7.794$ & $80.064 \pm 8.016$ \\
\hline KLK-6 (ng/mL) & $1.013 \pm 0.335^{*}$ & $0.741 \pm 0.178$ \\
\hline KLK-7 $(\mathrm{ng} / \mathrm{mL})$ & $0.803 \pm 0.234^{*}$ & $0.589 \pm 0.187$ \\
\hline KCNJ3 $(\mathrm{ng} / \mathrm{mL})$ & $0.897 \pm 0.288$ & $0.905 \pm 0.240$ \\
\hline KCNK9 $(\mathrm{ng} / \mathrm{mL})$ & $0.634 \pm 0.174$ & $0.554 \pm 0.156$ \\
\hline
\end{tabular}

${ }^{*} p<0.05$, compared to control group.

\section{DISCUSSION}

Aging is the accumulation of changes which increase the risk of mortality. Environmental and genetic factors and disease are the causes of aging. Oxidative stress is proposed as a key element in the aging process $(16,17)$. Furthermore, oxidant and antioxidant status may also cause the degenerative changes encountered in aging. Parkinson's Disease, $A D$, and stroke disease are the well-known examples of age-related neurodegenerative disorders (18).

$A D$ is the most common neurodegenerative disease, which is characterized with dysfunctions in cognitive abilities like execution function, attention, language, and visual skills, confusion, aggression, memory loss, and mood changes $(15,18,19)$, and results in death approximately 5-9 years after the diagnosis (20).

$A D$, represents another serious problem and is rising in prevalence worldwide, especially among the aging population (21). Although age and the inheritance of predisposing genetic factors appear to play a major role, more recent evidence suggest that the development and progression of $A D$ is subject to a wide variety of both environmental and genetic modifiers (22).
The enlightening of the pathogenesis of $A D$ will lead the way in slowing, stopping and improving the pathogenesis process in the development of new $A D$ preventive treatment strategies. For this reason, many studies were conducted on AD. However, the exact pathogenesis has not yet been enlightened, and the treatment method has not been identified yet (23).

When the pathogenesis of $A D$ is examined, it is observed that the intracellular and extracellular aggregations occur in certain parts of the brain. Although intracellular aggregation is seen as neurofibrillary glomus resulting due to hyperphotophosphorylation of the Tau protein in insoluble helical filaments, the extracellular accumulations are in the form of amyloid plaques which consist of $A B$ peptides in insoluble amyloid fibrils (24).

KLK's are a subgroup of cool protease that undertake various physiological functions in human metabolism. Although KLK's potential interest in neurological diseases is accepted at an increasing level, little is known about its pathophysiological effects. KLK's appear before us as an important mediator of neurological diseases like AD (25-27), frontotemporal dementia (28), Parkinson's Disease (26-30), Multiple Sclerosis (31-32), and Post-polio 
Syndrome (33). It has been shown that KLK's play roles in various pathologies, and are investigated now as a potential therapeutic target. Many studies show that KLK's has the potential to be the biological markers of cancer and neurological diseases (34).

In the present study, we aimed to analyze the potential of the age-related proteases KLK-6, and KLK-7 as a biomarker for AD.

Previous studies show that members of the human tissue KLK family are associated with malignancy. It has been speculated that some KLK's (KLK-5, 6, 7, 8,11 ) exist in the CNS, and might be associated with brain physiology and pathobiology (35).

Shimizu et al. (35) showed that KLK-1, 4, 5, 6, 7, 8, 10,11, 13 and 14 exist both in the cerebral cortex and in the hippocampus. It was determined in the study that KLK-8 mRNA levels increased 11.5-fold compared to the control group in the $A D$ hippocampus.

KLK-6 is known to be an age-related serine protease predominantly expressed within the brain and spinal cord, particularly in neurons and oligodendrocytes. It was previously shown to be involved in proteolysis of extracellular proteins implicated in neurodegenerative disease such as $A D$ prompting validation of KLK-6 as potential biomarker of diseases (25, 36-38). Diamandis et al. (25) found that the KLK-6 concentration in $A D$ brain tissue extracts was approximately twice as low as the extracts obtained from the normal control group. They reported that the full blood KLK-6 concentration in $A D$ patients was approximately ten times higher than KLK-6 concentration in normal controls.

The levels of KLK- 6 in the body fluids are increasing with age $(36,37)$. This age association was proposed to be disrupted in AD (38). Patra et al. (39) demonstrated that the plasma KLK-6 levels of $A D$ group were significantly increased compared with control group. In our study, it was also determined that the serum KLK-6 levels were significantly higher in the Alzheimer's group when compared to the control group.
Scarisbrick et al. (32) determined in an in vitro test which involved murine cortical neurons that KLK-1 and KLK-6 directly cause neuron loss. Probably, KLK's contribute to neurological function loss by causing direct axon damage and the death of neuron cells.

KLK-7 was originally identified as an inflammationinduced proteolytic enzyme in the skin. However, the expression level of KLK-7 was decreased in the cerebrospinal fluid and brains of $\operatorname{AD}$ patients $(28,40)$. Moreover, it was observed that KLK-7 is able to cleave the hydrophobic core motif of $A B$ fibrils, thereby attenuating neurotoxicity in vitro (41).

It was reported that expression of KLK-7 mRNA was significantly decreased in the brains of $A D$ patients (41). In our study, it was determined that the serum KLK-7 levels were significantly higher in the Alzheimer's group when compared to the control group.

Nevertheless, it remains unclear whether upregulation of KLK-7 in the brain causes noxious effect by degrading the other substrates. It is important to understand the physiological function and substrate of KLK-7 in the brain by a proteomic approach (4042).

Various potassium channels, which are active in different cells, especially in brain cells, have been identified. KCNK9 exists at low levels in normal tissues other than in the brain, and its physiological role is not yet clear. However, it is speculated that it has roles in respiration, aldosterone release, neuronal activity, and neuron apoptosis $(14,15)$.

Lee et al. (43) examined the suppressive role of the KCNJ3 destruction in tumor formation and concluded that the $\mathrm{KCNJ} 3$ destruction in cancerous cells causes the aging of cancer cells.

In our study, it was determined that the serum KCNJ3 and KCNK9 protein levels were not significant different in Alzheimer's group when compared to the control group. It is thought that the failure in preventing the abnormal protein folding and 
accumulation in brain leads to AD. However, according to the findings of the present study, a positive correlation was not detected between the levels of KCNJ3 and KCNK9 proteins and AD's pathology.

Aging is an inevitable biological process characterized by a general decline in various physiological functions and resistance to stress. Aging alone is one of the major risk factors for AD. But little is known about the molecular process that distinguish healthy aging from pathological aging. Process linked to inflammation is believed to play an important role in $A D$ pathogenesis. Serum KLK-6 and KLK-7 levels may be of value as a biomarker only for patients with advanced $A D$.

In conclusion, we can conclude that KLK-6 and KLK-7 levels can be used in the diagnosis of AD due to the increased serum levels in pathological AD. It is expected that this study would give a direction to new researches on this topic. There is a need for further studies on this subject.

\section{ETHICS COMITTEE APPROVAL}

* The study was approved by the Eskișehir Osmangazi University Clinic Research Committee and Human Ethical Committee (Date: 04.06.2020 and Number: 80558721-050.99-E.61665).

\section{CONFLICT OF INTEREST}

The authors declare no conflict of interest.

\section{REFERENCES}

1. Holtzman DM, Goate A, Kelly J, Sperling R. Mapping the road forward in Alzheimer's disease. Sci Transl Med, 2011; 3 (114): 114-48.

2. Ballard C, Gauthier S, Corbett A, Brayne C, Aarsland D, Jones E. Alzheimer's disease. Lancet, 2011; 377 (9770): 1019-31.

3. Sotiropoulou G, Pampalakis G, Diamandis EP. Functional roles of human kallikrein-related peptidases. J Biol Chem, 2009; 284 (48): 32989-94.

4. Parassas I, Elssa A, Poda G, Diamandis EP. Unleashing the therapeutic otential of human kallikreinrelated serine proteases. Nat Rev Drug Discovery, 2015; 14 (10): 183-202.
5. Borgono CA, Michael IP, Diamandis EP. Human tissue kallikreins: Physiologic roles and applications in cancer. Molecular Cancer Research, 2004; 2(5): 257-80.

6. Aronson JK. Potassium channels in nervous tissue. Biochem Pharmacology, 1992; 43 (1): 11-4.

7. Pongs O. Voltage-gatedpotassium channels: from hyperexcitability to excitement. FEBS Letters, 1999; 452 (1-2): 31-5.

8. Bronstein-Sitton S. $\mathrm{K}+$ channels and cancer. Pathways, 2006; 12 (1): 18-20. 
9. Kaneko S, Okada M, Iwasa H, Yamakawa K, Hirose S. Genetics of epilepsy: current status and perspectives. Neurosci Res, 2002; 44 (1): 11-30.

10. Marban E. Cardiac channelopathies. Nature, 2002; 415 (3): 213-18.

11. Jurkat- Rott K, LercheH, Lehmann-Horn F. Skeletal muscle channelopathies. J Neurol, 2002; 249 (1): 1493-1502.

12. Nichols CG, Koster JC. Diabetes and insulin secretion: whither KATP? Am J Physiol Endocrinol Metab, 2002; 283 (3): E403-12.

13. Olesen SP, Bundgaard M. ATP-dependent closure and reactivation of inward rectifier $\mathrm{K}+$ channels in endothelial cells. Circ Res, 1993; 73 (3): 492-95.

14. Bayliss DA, Sirois JE, Talley EM. The TASK family: two-pore domain background $\mathrm{K}+$ channels. Mol Interv, 2003; 3 (5): 205-19.

15. Lauritzen I, Zanzouri M, Honore E, Duprat F, Ehrengruber MU, Lazdunski M, et al. K+ dependent cerebellar granule neuron apoptosis. Role of task leak K+ channels. J Biol Chem, 2003; 278 (34): 32068-76.

16. Yildirim Z, Ucgun NI, Yildirim F. The role of oxidative stress and antioxidants in the pathogenesis of agerelated macular degeneration. Clinics (Sao Paulo), 2011; 66(5): 743-46.

17. Yildirim Z, Yildirim F, Ucgun NI, Dincel AS. Choroidal Neovascular Membrane in Age-Related Macular Degeneration is Associated with Increased Interleukin-6. International J Gerontology, 2012; 6(2): 101-4.

18. Gandhi S, Abramov AY. Mechanism of oxidative stress in neurodegeneration. Oxid Med Cell Longev, 2012; 2012: 1-11.

19. Sutherland GT, Chami B, Youssef P, Witting PK. Oxidative stress inAlzheimer's disease: Primary villain or physiological by-product? Redox Report, 2013; 18 (4): 134-41.

20. Wolfson C, Wolfson DB, Asgharian M, M'Lan CE, Ostbye $\mathrm{T}$, Rockwood $\mathrm{K}$, et al. A reevaluation of the duration of survival after the onset of dementia. N Eng J Med, 2001; 344 (15): 1111-16.
21. Alzheimer's A. Alzheimer's disease facts and figures. Alzheimers Dement, 2010; 6: 158-94.

22. Tanzi RE, Bertram L. Twenty years of the Alzheimer's disease amyloid hypothesis: a genetic perspsctive. Cell, 2005; 120: 545-55.

23. Yang $Y$, Song W. Molecular links between Alzheimer's disease and Diabetes mellitus. Neuroscience, 2013; 250: $140-50$.

24. Singh U, Devaraj S, Jialal I. Vitamin, oxidative stress, and inflammation. Annu Rev Nutr, 2005; 25: 151-74.

25. Diamandis EP, Yousef GM, Petraki C, Soosaipillai AR. Human kallikrein 6 as a biomarker of Alzheimer's disease. Clin Biochem, 2000; 33 (8): 663-67.

26. Ogawa K, Yamada T, Tsujioka Y, Taguchi J, Takahashi $M$, Tsuboi $Y$, et al. Localization of a novel type trypsin-like serine protease, neurosin, in brain tissues of Alzheimer's disease and Parkinson's disease. Psychiatry and Clin Neurosci, 2000; 54(4): 419-26.

27. Zarghooni M, Soosaipillai A, Grass L, Scorilas A, Mirazimi N, Diamandis EP. Decreased concentration of human kallikrein 6 in brain extracts of Alzheimer's disease patients. Clin Biochem, 2002; 35(3): 225-31.

28. Diamandis EP, Scorilas A, Kishi T, Blennow K, Luo LY, Soosaipillai A, et al. Altered kallikrein 7 and 10 concentrations in cerebrospinal fluid of patients with Alzheimer's disease and frontotemporal dementia. Clin Biochem, 2004; 37(3): 230-37.

29. Menendez-Gonzalez M, Castro-Santos P, Calatayud MT, Perez-Pinera P, Ribacoba R, Martinez-Rivera M, et al. Plasmatic level of neurosin predicts outcome of mild cognitive impairment. Int Arch Med, 2008; 1(11): 1-7.

30. Iwata A, Maruyama M, Akagi T, Hashikawa T, Kanazawa I, Tsuji S, et al. Alpha-synuclein degradation by serine protease neurosin: implication for pathogenesis of synucleinopathies. Hum Mol Genet, 2003; 12(20): 2625-35.

31. Scarisbric IA, Blaber SI, Lucchinetti CF, Genain CP, Blaber M, Rodriguez M. Activity of a newly identified serine protease in CNS demyelination. Brain, 2002; 125(6): 1283-96. 
32. Scarisbrick IA, Linbo R, Vandell AG, Keegan $M$, Blaber SI, Blaber M, et al. Kallikreins are associated with secondary progressive multiple sclerosis and promote neurodegeneration. Biol Chem, 2008; 389(6): 739-45.

33. Gonzalez H, Ottervald J, Nilsson KC, Sjogren $\mathrm{N}$, Miliotis $\mathrm{T}$, Von Bahr $\mathrm{H}$, et al. Identification of novel candidate protein biomarkers for the post-polio syndrome implications for diagnosis, neurodegeneration and neuroinflammation. J Proteomics, 2009; 71(6): 670-81.

34. Huang X, Moir RD, Tanzi RE, Bush AL, Rogers JT. Redox-active metals, oxidative stress and Alzheimer's disease pathology. Ann NY Acad Sci, 2004; 1012: 153-63.

35. Shimizu-Okabe C, Yousef GM, Diamandis EP, Yoshida $S$, Shiosaka S, Fahnestock M. Expression of the kallikrein gene family in normal and Alzheimer's disease brain. Neuroreport, 2001; 12 (12): 2747-51.

36. Bayani J, Diamandis EP. The physiology and pathobiology of human kallikrein-related peptidase 6 (KLK6). Clin Chem Lab Med, 2011; 50 (2): 211-33.

37. Menendez-Gonzalez M, Castro-Santos P, Suarez A, Calatayud MT, Perez-Pinera P, Martinez-Rivera $M$, et al. Value of measuring plasmatic levels of neurosin in the diagnosis of Alzheimer's disease. J Alzheimers Dis, 2008; 14 (1): 59-67.
38. Mitsui S, Okui A, Uemura H, Mizuno T, Yamada T, Yamamura Y, et al. Decreased cerebrospinal fluid levels of neurosin (KLK6), an aging-related protease, as a possible new risk factor for Alzheimer's disease. Ann N Y Acad Sci, 2002; 977: 216-23.

39. Patra K, Soosaipillai A, Sando SB, Lauridsen C, Berge G, Meller I, et al. Assessment of kallikrein 6 as a cross-sectional and longitudinal biomarker for Alzheimer's disease. Alzheimers Res Ther, 2018; 10 (1): 1-11.

40. Bossers K, Wirz KT, Meerhoff GF, Essing AH, van Dongen JW, Houba P, et al. Concerted changes in transcripts in the prefrontal cortex precede neuropathology in Alzheimer's disease. Brain, 2010; 133: $3699-3723$.

41. Shropshire TD, Reifert J, Rajagopalan S, Baker D, Feinstein SC, Daugherty PS. et al. Amyloid beta peptide cleavage by kallikren 7 attenuates fibril growth and rescues neurons from Abeta-mediated toxicity in vitro. Biol Chem, 2014; 395: 109-18.

42. Kidana K, Tatebe T, Ito K, Hara N, Kakita A, Saito $T$, et al. Loss of kallikrein-related peptidase 7 exacerbates amyloid pathology in Alzheimer's disease model mice. EMBO Mol Med, 2018; 10 (3): 1-13.

43. Lee I, Park C, Kang WK. Knockdown of inwardly rectifying potassium channel Kir2. 2 suppresses tumorigenesis by inducing reactive oxygen speciesmediated cellular senescence. Mol Cancer Ther, 2010; 9(11): 2951-59. 